\title{
Modulation of epithelial sodium channel in human alveolar epithelial cells by lipoxin A4 through AhR-cAMP-dependent pathway
}

\author{
Bi-Huan Cheng ${ }^{1,2}$, Li-Wei Pan ${ }^{2}$, Sheng-Rong Zhang ${ }^{3}$, Bin-Yu Ying ${ }^{2}$, Ben-Ji \\ Wang $^{2}$, Guo-Liang Lin ${ }^{2}$ and Shi-Fang Ding ${ }^{1^{\star}}$ \\ ${ }^{1}$ Department of Critical Care Medicine, Qilu Hospital of Shandong University, Jinan, ${ }^{2}$ Department of Anesthesia and Critical \\ Care, The Second Affiliated Hospital and Yuying Children's Hospital of Wenzhou Medical University, Wenzhou, ${ }^{3}$ Department of \\ Critical Care Medicine, Qingtian Peoples Hospital Lishui, PR China
}

*For correspondence: Email: shifangdingsd@163.com; Tel: 0086-577-88002806; Fax: 0577-88832693

\begin{abstract}
Purpose: To investigate the effect of lipoxin A4 (LXA4) on the expressions of protein and mRNA of alveolar epithelial sodium channel (ENaC) in normal and lipopolysaccharide (LPS)-stimulated A549 cells.

Methods: A549 cell-lines were randomized into 11 groups $(N=8)$ and treated. EnaC level was evaluated by Western blot. Total RNA was extracted and reverse-transcribed and then levels of ENaC mRNA, cGMP and cAMP in the cells were determined.

Results: $L X A 4\left(10^{-7} \mathrm{~mol} / \mathrm{L}\right)$ increased the expressions of $\alpha$-subunit of ENaC relative to $L P S$ group. In addition, LXA4 significantly up-regulated the expression of mRNAs of $\alpha, \beta$ and $y$ subunits of $E N a C$ ( $p<$ 0.01 ). The level of $C A M P$ was increased in $L X A 4$ group, but significantly reduced in LPS group relative to control group $(p<0.05)$. However, treatment with LXA4 annulled the increased cAMP concentration, compared with LPS group $(p<0.05)$

Conclusion: These results show that LXA4 influences ENaC up-regulation in normal and LPS stimulated A549 alveolar epithelial cells.
\end{abstract}

Keywords: Acute lung injury, Alveolar epithelial sodium channel, Lipoxin A4, AhR, cAMP, cGMP

Tropical Journal of Pharmaceutical Research is indexed by Science Citation Index (SciSearch), Scopus, International Pharmaceutical Abstract, Chemical Abstracts, Embase, Index Copernicus, EBSCO, African Index Medicus, JournalSeek, Journal Citation Reports/Science Edition, Directory of Open Access Journals (DOAJ), African Journal Online, Bioline International, Open-J-Gate and Pharmacy Abstracts

\section{INTRODUCTION}

Acute lung injury (ALI) and acute respiratory distress syndrome (ARDS) lead to respiratory failure and pulmonary edema [1]. Alveolar epithelial injury is a major contributor to alveolar flooding. Injury to alveolar epithelium prevents reabsorption of edema fluid, a key step in the resolution of ALI/ARDS [1,2]. Earlier studies showed that alveolar epithelial sodium channel $(\mathrm{ENaC})$ and Na-K-ATPase play critical roles in reducing edema in ALI/ARDS [3,4].
Lipoxins (LXs), as anti-inflammatory and proresolution mediators, have been extensively studied in various inflammatory diseases, as well as their interactions with lipoxin $A_{4}\left(L_{X} A_{4}\right)$ receptors [5,6]. These receptors includde LXR (lipoxin receptor), cysLT 1 (cysteinyl leukotriene receptor 1), cysLT 2 (cysteinyl leukotriene receptor 2) and AhR (aromatic hydrocarbon receptor) [7]. Previous studies have demonstrated that post-treatment with $\mathrm{LXA}_{4}$ significantly reduced ALI in LPS-stimulated mice [8]. A recent report showed that $L X A_{4}$ improved $\mathrm{ENaC}$ expression through ALX-cGMP signaling 
pathways, resulting in enhanced clearance of alveolar fluid in oleic acid-stimulated animals [9].

The present study aims to test the hypothesis that $\mathrm{LXA}_{4}$ increases ENaC protein and mRNA expressions in normal and LPS-stimulated A549 cells. In addition, it investigated $L X A_{4}$ receptors, ALX, AhR, cysLRT 1 and cysLRT $T_{2}$ to determine the key receptors involved in up-regulation of $\mathrm{ENaC}$ function in A549 cells, as well as the levels of cAMP and cGMP in A549 cells.

\section{EXPERIMENTAL}

\section{Materials}

Lipopolysaccharide (LPS; E. coil serotype 055: B5) and AhR inhibitor, a-naphthoflavone (ANF) were purchased from Sigma (St. Louis, MO). Lipoxin $\mathrm{A}_{4}$ was obtained from Cayman Chemical Company (Ann Arbor, MI). CysLT2 receptor inhibitor, BAY-u9773 was from Bimol Company (Farmingdale, NY). RPMI Medium 1640 and FCS were purchased from Gibco (Grand Island, NY). Saline citrate-buffered streptomycin and penicillin were products of Invitrogen (CA). The $\alpha, \beta$ and $y$ subunits of anti- $\mathrm{ENaC}$ were products of Abcam Company (Cambridge, MA), while anti- $\beta$-actin was supplied by Santa Cruz Company (Santa Cruz, CA). ELISA kits for cAMP and cGMP were purchased from R\&D systems (Minneapolis, MN). Rp-cAMP (cAMP inhibitor) was obtained from Biomol-Enzo Life Sciences (Farmingdale, NY), while BCA protein assay kits and RT-PCR kits were purchased from Thermo Scientific (Rockford, IL). Real-time PCR Master Mix (SYBR Green) was obtained from Toyobo (Japan).

\section{Cell culture and treatment}

Human epithelial cell line (A549 cell line) was obtained from Basic Medical Sciences of Zhejiang Wenzhou Medical University. The cell line was cultured at $37{ }^{\circ} \mathrm{C}$ in a $5 \% \mathrm{CO}_{2}$ humidified atmosphere, in RPMI 1640 medium containing $10 \%$ fetal calf serum (FCS), $100 \mathrm{U} / \mathrm{ml}$ penicillin $\mathrm{G}$ and $100 \mu \mathrm{g} / \mathrm{mL}$ streptomycin. The cells were sub-cultured into six-well plates to 80 $\%$ sub-confluence; $100 \%$ confluent cells were maintained for $24 \mathrm{~h}$ in low serum medium (PRMI containing $0.1 \%$ FCS). Thereafter, the cells were randomized into eleven groups $(n=8)$ : control, LPS $(1 \mu \mathrm{g} / \mathrm{mL})$, LPS + ethanol $(3.7 \mu \mathrm{l} / \mathrm{mL})$, LPS + $\mathrm{LXA}_{4}\left(10^{-9} \mathrm{M}\right), \mathrm{LPS}+\mathrm{LXA}_{4}\left(10^{-8} \mathrm{M}\right), \mathrm{LPS}+\mathrm{LXA}_{4}$ $\left(10^{-7} \mathrm{M}\right)$, LPS $+\operatorname{LXA}_{4}\left(10^{-6} \mathrm{M}\right), \mathrm{LXA}_{4}\left(10^{-7} \mathrm{M}\right)$, ethanol, $\operatorname{LXA}_{4}\left(10^{-7} \mathrm{M}\right)+\mathrm{BAY}-\mathrm{u} 9773(3 \mu \mathrm{M})$ and $\mathrm{LXA}_{4}\left(10^{-7} \mathrm{M}\right)+$ ANF (1 nM) groups. In each group, the reagents were added simultaneously to stimulated cells and incubated for 6, 12 and 24 h. At the end of incubation, the cells were harvested and subjected to sonication.

\section{Western blot for $\alpha, \beta$ and $y$ subunits of EnaC}

Samples were lysed in standard RIPA lysis solution composed of $50 \mathrm{mM}$ Tris buffer, $\mathrm{pH}$ 7.4, $150 \mathrm{mM} \mathrm{NaCl}, 1 \%$ Triton $\mathrm{X}-100,1 \%$ sodium deoxycholate, $0.1 \%$ SDS, $4 \mathrm{mM}$ sodium pyrophosphate, $5 \mathrm{mM}$ sodium fluoride, $1 \mathrm{mM}$ EDTA, $0.02 \mathrm{mM}$ leupeptin and $1 \mathrm{mM}$ phenylmethyl sulfonylfluoride (PMSF) on ice for $30 \mathrm{~min}$, and thereafter centrifuged for $10 \mathrm{~min}$ at $12,000 \mathrm{rpm}$. The protein contents of the supernatants were estimated using BCA protein assay kitx. The protein mixture from the supernatants $(80 \mu \mathrm{g})$ were separately boiled to achieve denaturation, and then subjected to $10 \%$ SDS-PAGE prior to transfer onto PVDF membranes. Following blocking for $2 \mathrm{~h}$ with $5 \%$ non-fat dry milk in TBS-T buffer, expression of the a subunit of ENaC was determined using primary anti-epithelial sodium channel alpha antibody (1:750). The expression of the $\beta$ subunit was determined using primary anti-SCNN1B antibody (1:500), while the expression of $\mathrm{Y}$ subunit was measured using primary antiepithelial sodium channel gamma antibody $(1: 1000)$, and secondary goat anti-rabbit lgG. $\beta$ actin was used as internal control. Detection of the bound antibody was carried out on X-ray films by enhanced chemiluminescence (ECL).

\section{RNA isolation, reverse transcriptase and PCR}

Total RNA was extracted using Trizol reagent according to manufacturer's protocol. One (1) microgram of RNA sample was reversetranscribed into complementary DNA (cDNA) using a RT-PCR kit on the MJ Mini Thermal Cycler (Bio-Rad, Hercules, CA, USA), according to the manufacturer's instructions. The primer sequences used for PCR amplification are in Table 1.

Then semi-quantitative analysis was performed by UVP-gel densitometry.

\section{Quantitative real-time PCR}

Levels of ENaC mRNA in A549 cells were determined with SYBR Prime Script Kit on the CFX96 Real-Time PCR Detection System (BioRad, Hercules, CA, USA). Primers used for amplification are in Table 2.

Data was analyzed as previously described [9] using GAPDH as a reference gene. 
Table 1: Primer sequence

\begin{tabular}{lcc}
\hline Gene & Sequence length (bp) & Primer sequence \\
\hline ALX & 173 & 5'-TCCATTGTTGCCATCTGCTAT-3' (sense) \\
AhR & 469 & 5'-AACATCTCT TTGAGCCAGACG-3'(antisense); \\
& 5'-TTAACGGATGAAATCCTGACG-3' (sense) \\
CysLTR1 & 437 & 5'-AAGTAGTGGGGTATGGGGATG-3' (antisense) \\
CysLTR2 & 222 & 5'-GCCAGGTTTGTGTGTGTAGGT-3' (sense) \\
3-actin & 204 & 5'- GCAGCCAGAGACAAGGTTATG -3' (antisense); \\
& & 5'-TTGTGTTTCCTGCCCTATCAC-3'(sense) \\
& 5'-CTTTGTCTTTGCCTTCTGTGG-3' (antisense); \\
\end{tabular}

Table 2: Primers for amplification

\begin{tabular}{lcc}
\hline Variable & Sense & Antisense \\
\hline a-ENaC & 5'-CAGCCCATACCAGGTCTCAT-3' & 5'- ATGGTGGTGTTGTTGCAGAA-3' \\
B-ENaC & 5'- ATGGTGGTGTTGTTGCAGAA-3' & 5'- CCAGGAAGGAGAAAACCACA-3' \\
Y-ENaC & 5'- ACCACCAGCCATGGTCTAAG-3' & 5'- GTTCAGGTCCCGGGATTTAT-3' \\
GAPDH & 5'- GAGTCAACGGATTTGGTCGT-3' & 5'-TTGATTTTGGAGGGATCTCG-3' \\
\hline
\end{tabular}

\section{cAMP and cGMP assays}

A549 cells were prepared, plated into six-well plates at a density $10^{5} /$ well and maintained subconfluent $(80 \%)$. Confluent cells $(100 \%)$ were maintained for $24 \mathrm{~h}$ in serum-free medium, then treated with LPS $(1 \mu \mathrm{g} / \mathrm{ml}), \mathrm{LXA}_{4}\left(10^{-7} \mathrm{M}\right)$, BAYu9773 $(3 \mu \mathrm{M})$ or ANF $(1 \mathrm{nM})$ for $24 \mathrm{~h}$. The supernatants recovered after centrifugation were analyzed for contents of cAMP and cGMP by ELISA.

\section{Statistical analysis}

Data are expressed as mean \pm SEM, and groups were compared by one-way ANOVA followed by Newman-Keuls multiple inter-group comparisons, using SPSS version 16.0 software. A probability of $p<0.05$ was considered significant.

\section{RESULTS}

Dose-dependency of $\mathrm{LXA}_{4}$ regulated ENaC expression in A549 cells stimulated with LPS

In all responses, only $10^{-7} \mathrm{M} \mathrm{LXA}$ increased $\mathrm{ENaC}$ a subunit expression when compared with LPS group (Figure 1A). However, the expressions of the $\beta$ and $y$ subunits of $E N a C$ were increased dose-dependently, peaking at $10^{-}$ ${ }^{7} \mathrm{M} \mathrm{LXA}_{4}$ (Figure 1B and C). Therefore, in subsequent experiments, the expression of $\mathrm{ENaC}$ in A549 cells treated with LPS was assessed using $10^{-7} \mathrm{M} \mathrm{LXA}_{4}$.

Time-dependency of $\mathrm{LXA}_{4}$ regulated ENaC expression in A549 cells stimulated with LPS

At $6 \mathrm{~h}$, LPS significantly decreased the expressions of $\alpha, \beta$ and $\gamma$ subunits of $E N a C$ when compared with control group $(p<0.01)$; while $\mathrm{LXA}_{4}$ significantly increased the expressions of these subunits, compared with control group ( $p<0.01$; Figure 2). At $12 \mathrm{~h}$, the protein levels of the $\alpha, \beta$ and $y$ subunits were decreased in the LPS group, but elevated in the LPS $+L^{2 X A_{4}}$ group relative to the LPS group $(p<$ 0.05 ; Figure 3). At $24 \mathrm{~h}$, the levels of the $\alpha, \beta$ and y subunits of $\mathrm{ENaC}$ were significantly decreased in the LPS group, but increased in the LPS + $\mathrm{LXA}_{4}$ group when compared with the LPS group $(p<0.01$; Figure 4$)$. Therefore, in subsequent experiments, the effect of $\mathrm{LXA}_{4}$ on $\mathrm{ENaC}$ expression in LPS-stimulated A549 cells was assessed at $24 \mathrm{~h}$.

\section{Effect of $\mathrm{LXA}_{4}$ on the ENaC mRNA expression in A549 cells stimulated with LPS}

The cells were incubated with LPS $(1 \mu \mathrm{g} / \mathrm{mL})$ with or without $\mathrm{LXA}_{4}\left(10^{-7} \mathrm{M}\right)$ for $6 \mathrm{~h}$. It was found that $\mathrm{LXA}_{4}$ significantly up-regulated the expressions of mRNAs of $\alpha, \beta$ and $y$ subunits of ENaC $(p<$ 0.01 ), and LPS decreased the mRNA level of $\mathrm{ENaC} \alpha$ subunit relative to the control group $(p<$ 0.05 ; Figure $5 A$ ). However, no significant change in mRNA expression of $\beta$ and $y$ subunits was observed $(p>0.05$; Figure 5B and C). Interestingly, the expressions of mRNAs of the $\beta$ and $y$ subunits of ENaC were increased in LPS + $\mathrm{LXA}_{4}$ group when compared with LPS group $(p<$ $0.05)$, but not the $\mathrm{ENaC}$ a subunit.

\section{Receptors of LXA 4 on A549 cells}

As shown in Figure 6, $\mathrm{LXA}_{4}$ receptor cysLT $\mathrm{T}_{2}$ and AhR mRNA were expressed in A549 cells. However, cysLT 1 and LXR mRNA were not expressed in A549 cells. 


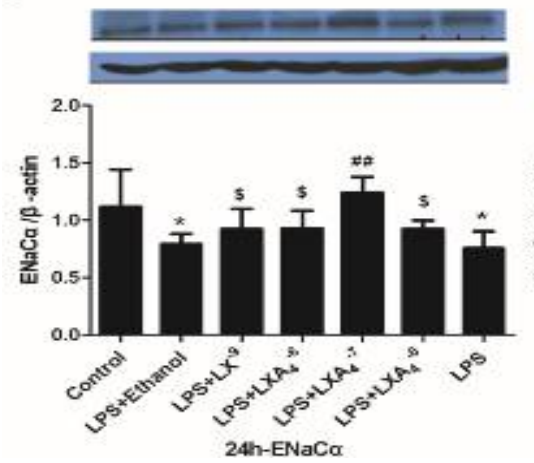

B

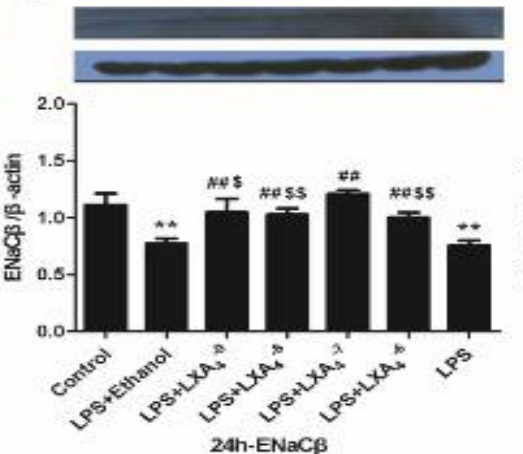

c

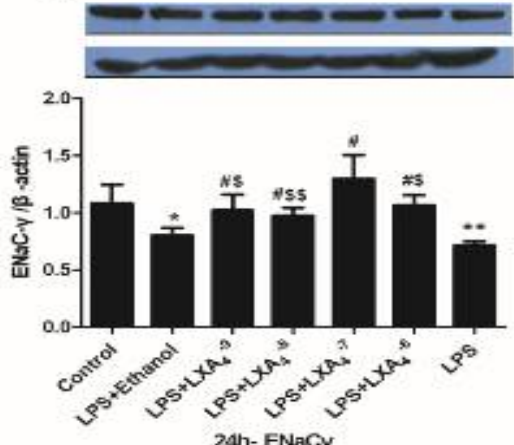

Figure 1: Effect of different concentrations of $L^{2 X A_{4}}$ on the expressions of the $\alpha, \beta$ and $y$ subunits of ENaC after $24 \mathrm{~h}$ in LPS-treated A549 cells. A549 cells were treated with $L X A_{4}\left(10^{-6}, 10^{-7}, 10^{-8}, 10^{-9} \mathrm{M}\right)$ in the presence of LPS (1 $\mathrm{g} / \mathrm{mL})$ for $24 \mathrm{~h}$. Cells were then harvested, and sonicated. ENaCa $(A), \beta$ $(B)$ and $y(C)$ subunits protein were measured by western blotting. Results are presented as mean \pm SEM for each group. ${ }^{*} p<0.05,{ }^{* *} p<0.01$ compared to control group, ${ }^{\#} p<0.05,{ }^{\# \#} p<0.01$ relative to LPS group, ${ }^{\$} p<0.05,{ }^{\$ \$} p<0.01$ compared to $L P S+L X A_{4}\left(10^{-7} M\right)$ group $(n=4)$. Ethanol was the resolvent

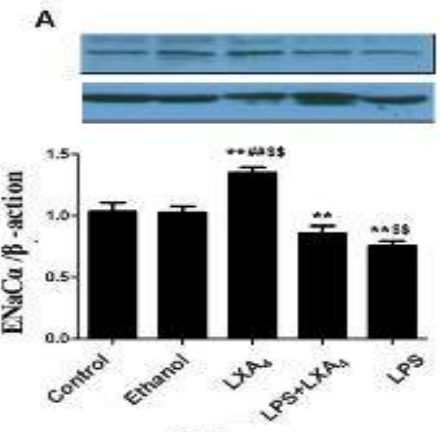

$6 \mathrm{~h}$

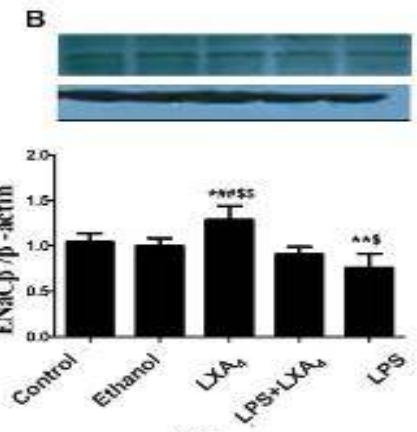

$6 \mathrm{~h}$

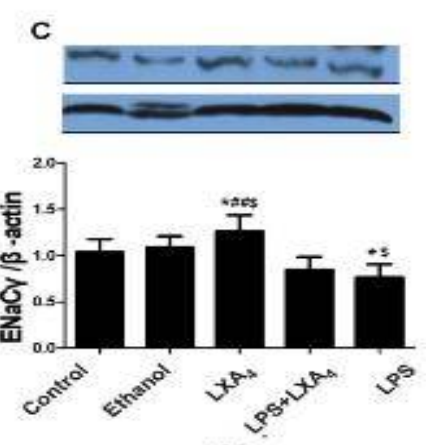

$6 \mathrm{~h}$

Figure 2: Effect of $\mathrm{LXA}_{4}$ on $\mathrm{ENaC} \alpha, \beta$ and $\mathrm{y}$ subunits protein expression at $6 \mathrm{~h}$ in LPS-induced $\mathrm{A} 549$ cells. A549 cells were treated with $L X A_{4}\left(10^{-7} \mathrm{M}\right)$ in the presence or absence of $L P S(1 \mu \mathrm{g} / \mathrm{ml})$ for $6 \mathrm{~h}$. Cells were then harvested, and sonicated. ENaCa $(A, D, G), \beta(B, E, H)$ and $y(C, F, I)$ protein expressions at $6 \mathrm{~h}$ were determined by western blotting. Data are expressed as mean \pm SEM for each group. ${ }^{*} p<0.05,{ }^{* *} p<0.01$ versus Control group, ${ }^{\#} p<0.05,{ }^{\# \#} p<0.01$ versus $L P S$ group, ${ }^{\$} p<0.05$, $\$_{\$} p<0.01$ versus Ethanol group $(n=4)$. Ethanol is resolvent

A
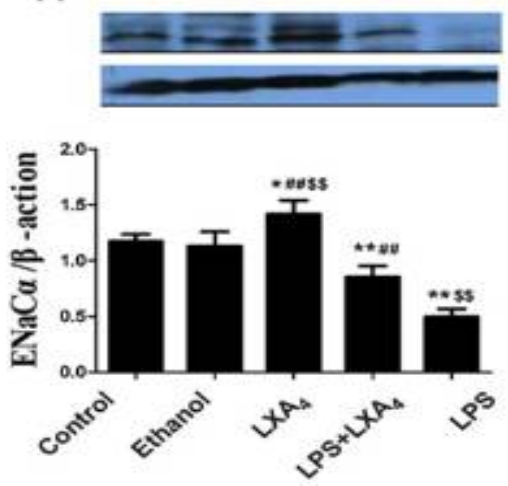

$12 \mathrm{~h}$
B
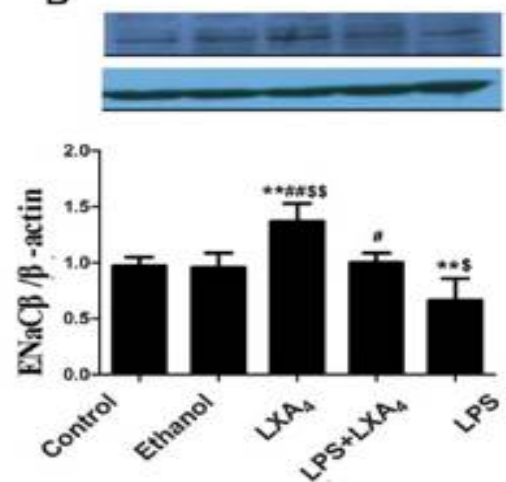

$12 \mathrm{~h}$
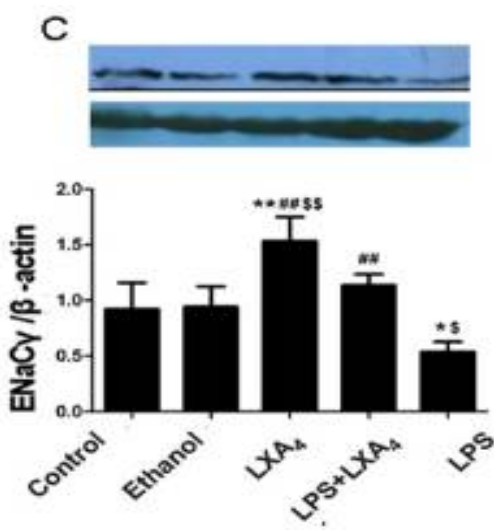

$12 \mathrm{~h}$

Figure 3: Effect of $\mathrm{LXA}_{4}$ on ENaCa, $\beta$ and $\mathrm{y}$ subunits protein expression at $12 \mathrm{~h}$ in LPS-induced A549 cells. A549 cells were treated with $L X A_{4}\left(10^{-7} \mathrm{M}\right)$ in the presence or absence of $L P S(1 \mu \mathrm{g} / \mathrm{ml})$ for $12 \mathrm{~h}$. Cells were then harvested, and sonicated. ENaCa $(A, D, G), \beta(B, E, H)$ and $\gamma(C, F, I)$ protein expressions at $12 \mathrm{~h}$ were determined by western blotting. Data are expressed as mean \pm SEM for each group. ${ }^{\star} p<0.05,{ }^{\star *} p<0.01$ versus Control group, ${ }^{\sharp} p<0.05,{ }^{\# \#} p<0.01$ versus $L P S$ group, ${ }^{\$} p<$ $0.05,{ }^{\$} p<0.01$ versus Ethanol group $(n=4)$. Ethanol is resolvent 
A

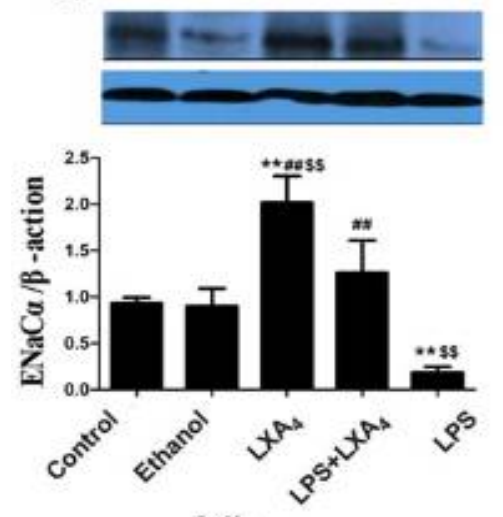

$24 \mathrm{~h}$
B
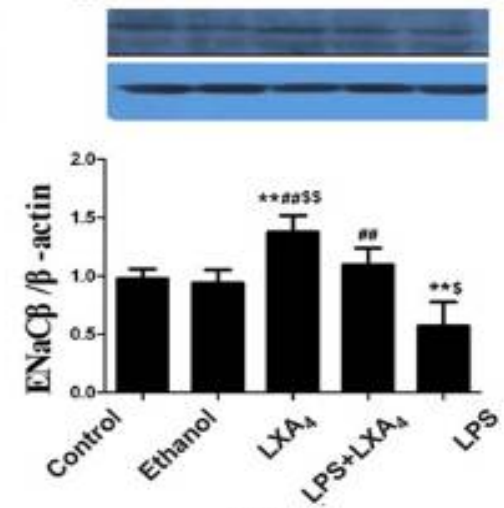

$24 \mathrm{~h}$
C
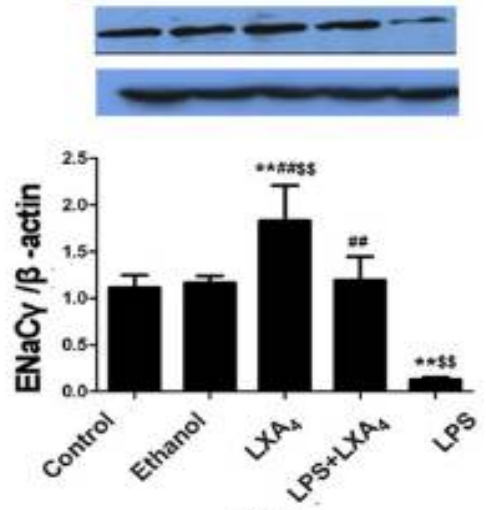

$24 \mathrm{~h}$

Figure 4: Effect of $\mathrm{LXA}_{4}$ on expressions of $\alpha, \beta$ and $\mathrm{y}$ subunits of ENaC at $24 \mathrm{~h}$ in LPS-induced A549 cells. A549 cells were exposed to $L X A_{4}\left(10^{-7} \mathrm{M}\right)$ in the presence or absence of $L P S(1 \mu \mathrm{g} / \mathrm{ml})$ for $24 \mathrm{~h}$. The cells were then harvested, and sonicated. ENaCa $(A, D, G), \beta(B, E, H)$ and $\gamma(C, F, I)$ protein expression at $24 h$ were determined using western blotting. Data are expressed as mean \pm SEM for each group. ${ }^{*} p<0.05,{ }^{* *} p<0.01$ versus Control group, ${ }^{\#} p<0.05,{ }^{\#} p<0.01$ versus LPS group, ${ }^{\$} p<0.05,{ }^{\$} p<0.01$ versus Ethanol group $(n=4)$; ethanol was resolvent
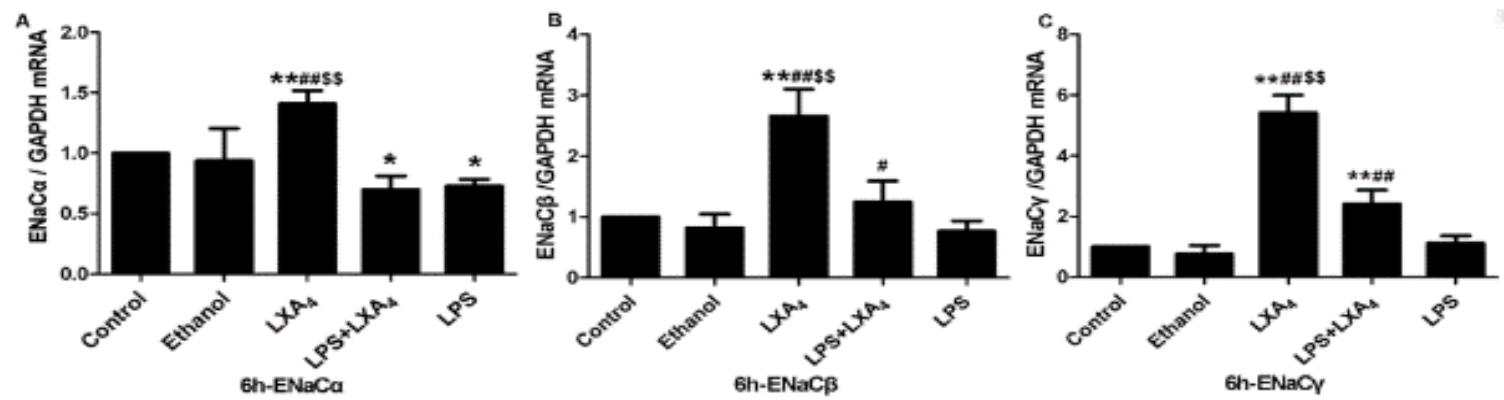

Figure 5: The effect of $\mathrm{LXA}_{4}$ on the expressions of mRNAs of the $\alpha, \beta$ and $y$ subunits of ENaC at $6 \mathrm{~h}$ in LPSinduced A549 cells. A549 cells were treated with $L X A_{4}\left(10^{-7} \mathrm{M}\right)$ in the presence and absence of $L P S(1 \mu \mathrm{g} / \mathrm{ml})$. After incubating for $6 \mathrm{~h}$, the ENaC $\alpha(A), \beta(B)$, and $\gamma(C)$ subunits $m R N A$ expressions were determined by realtime PCR. Data are expressed as mean \pm SEM for each group. ${ }^{*} p<0.05,{ }^{\star \star} p<0.01$ versus control group, ${ }^{\#} p<$ $0.05,{ }^{\# \#} p 0.01$ versus LPS group, ${ }^{\$} p<0.05,{ }^{\$ \$} p<0.01$ versus Ethanol group $(n=8)$. Ethanol was resolvent.

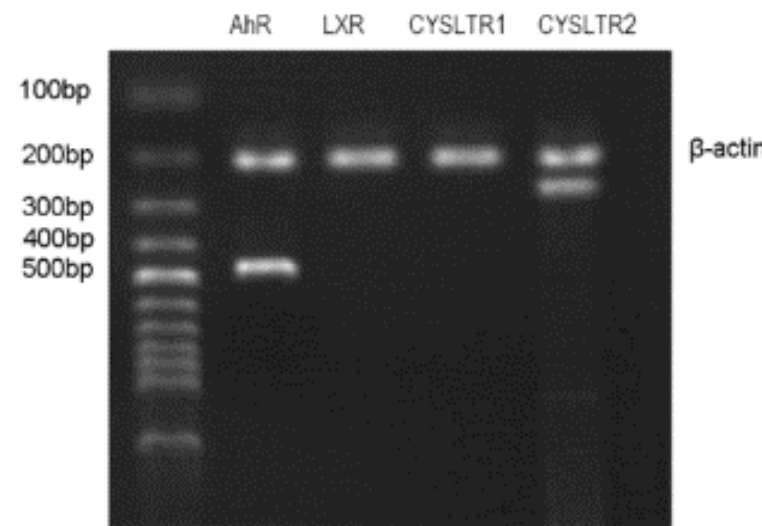

Figure 6: The expression of $\mathrm{LXA}_{4}$ receptors in A549 cells. A549 cells were treated with $L X A_{4}$ $\left(10^{-7} \mathrm{M}\right)$ for $24 \mathrm{~h}$. After incubation, the cells were harvested and sonicated. ALX (lipoxin receptor), AhR (aromatic hydrocarbon receptor), cysLRT1 (cysteinyILT1 receptor) and CysLRT (cysteinylL $T_{2}$ receptor) were determined by reverse transcriptase-polymerase chain reaction $(n=8)$.

\section{Effect of $L X A_{4}$ receptors on expression of ENaC protein in A549 cells following LPS exposure}

Protein expressions of the $\alpha, \beta$ and $y$ subunits of $\mathrm{ENaC}$ were up-regulated by $\mathrm{LXA}_{4}$, but were blocked by the $\mathrm{LXA}_{4}$ receptor inhibitor, ANF. However, BAY-u9773 was not inhibitory (Figure 7).

\section{$\mathrm{LXA}_{4}$ promoted ENaC expression}

To test whether $\mathrm{LXA}_{4}\left(10^{-7} \mathrm{M}\right)$ had an impact on cAMP and cGMP levels in A549 cells, we measured CAMP and cGMP concentration in A549 cells exposed to LPS $(1 \mu \mathrm{g} / \mathrm{mL})$ for $24 \mathrm{~h}$ by ELISA kits. It was found that CAMP concentration was increased in the $\mathrm{LXA}_{4}$ group, but was reduced in the LPS group relative to control group $(p<0.05)$. , and treatment with $\mathrm{LXA}_{4}$ reversed the increased CAMP concentration when compared with the LPS group $(p<0.05$; Figure 8A). In addition, when BAY-u9773 (cysLT 2 


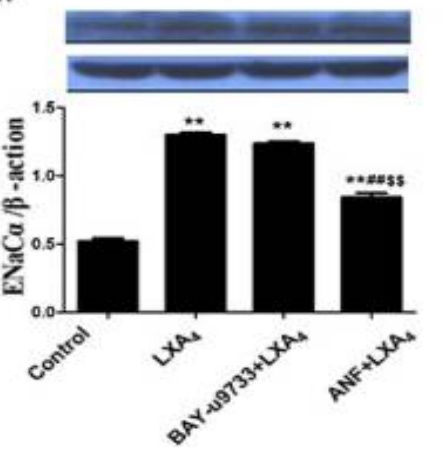

B

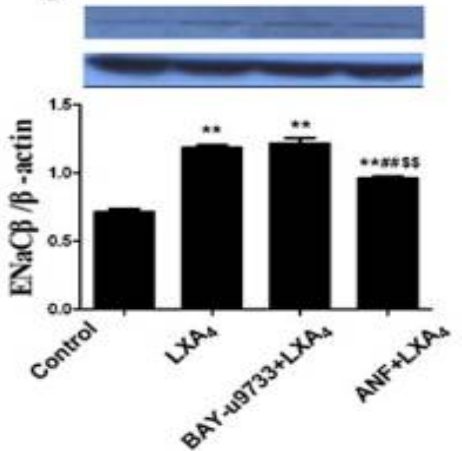

c

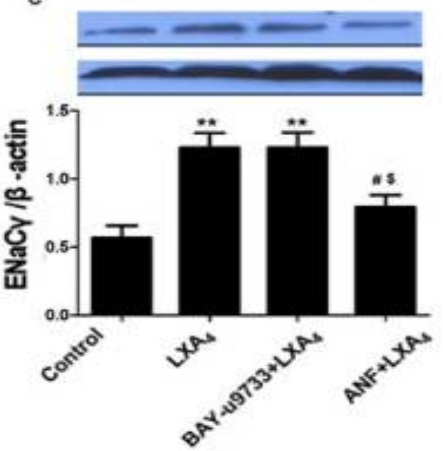

Figure 7: The effect of $\mathrm{LXA}_{4}$ receptor antagonists on protein expression of $\mathrm{ENaC}$ in $\mathrm{LXA}_{4}\left(10^{-7} \mathrm{M}\right)$-treated $\mathrm{A} 549$ cells. A549 cells were exposed to $L X A_{4}$ for $24 \mathrm{~h}$ in the presence of either BAY-u9733 (cysLRT $T_{2}$ antagonist, $3 \mu M$ ) or ANF (AhR antagonist, $1 \mathrm{nM})$. After harvesting the cells and sonicating them, the protein expressions of the $\alpha$ $(A), \beta(B)$ and $y(C)$ subunits of ENaC were determined by western blotting. Data are mean $\pm S E M .{ }^{*} p<0.05,{ }^{* *} p$ $<0.01$ relative to control, ${ }^{\#} p<0.05,{ }^{\# \#} p<0.01$ relative to LPS group, ${ }^{\$} p<0.05,{ }^{\$ \$} p<0.01$ versus ethanol group ( $n$ $=4)$
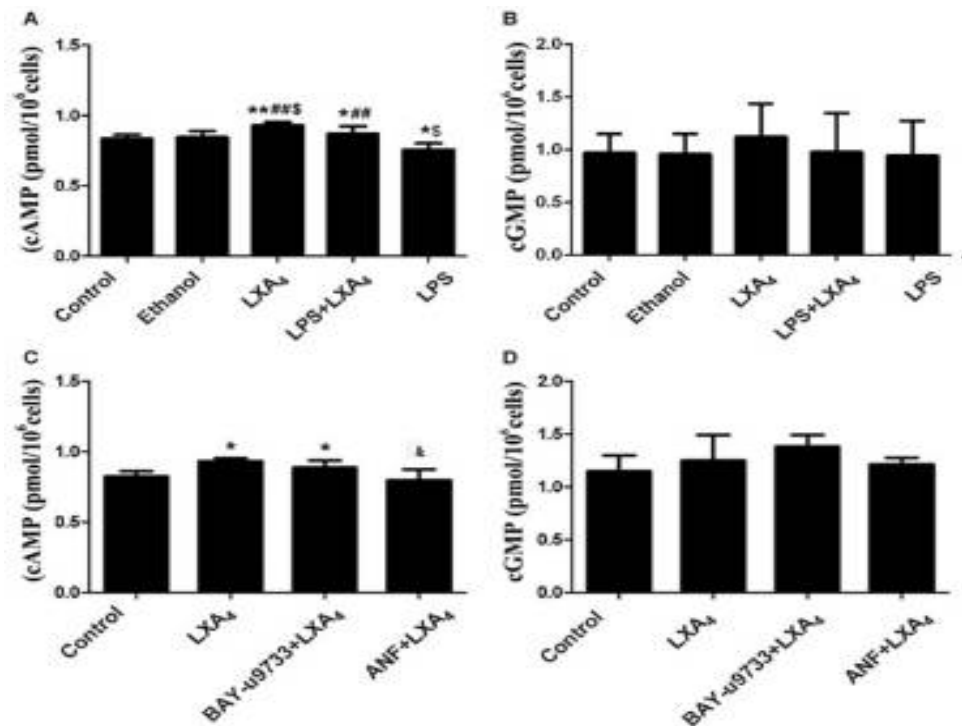

Figure 8: Effect of $\mathrm{LXA}_{4}$ and $\mathrm{LXA}_{4}$ receptor antagonists on cAMP and cGMP in A549 cells. A549 cells were treated with $L X A_{4}\left(10^{-7} \mathrm{M}\right)$ in the presence and absence of $L P S(1 \mu \mathrm{g} / \mathrm{mL}), B A Y-u 9773$ (cys $L R T_{2}$ antagonist, $\left.3 \mu M\right)$ or ANF (AhR antagonist, $1 \mathrm{nM})$ for $24 \mathrm{~h}$. CAMP (A) and cGMP (B) protein concentration of suspension were determined by ELISA kits. Data are expressed as mean \pm SEM for each group. ${ }^{*} p<0.05$, ${ }^{*} p<0.01$ versus control group, ${ }^{\#} p<0.05,{ }^{\# \#} p<0.01$ versus LPS group, ${ }^{\$} p<0.05,{ }^{\$} p<0.01$ versus Ethanol group, ${ }^{\&} p<0.05$ versus $L X A_{4}$ group $(n=8)$. Ethanol was resolvent

antagonist, $3 \mu \mathrm{M}$ ) and ANF (AhR antagonist, $1 \mathrm{nM})$ were used to treat $\mathrm{A} 549$ cells in the presence of $\mathrm{LXA}_{4}$ for $24 \mathrm{~h}$, cAMP concentration was decreased in the $L X A_{4}+$ ANF group relative to the $L X A_{4}$ group $(p<0.05)$, but not in the $L X A_{4}$ + BAY-u9773 group (Figure 8C). However, no significant change was seen in CGMP levels in these groups (Figure 8B \& Figure 8D).

The protein levels of $\alpha, \beta$ and $\gamma$ subunits were markedly decreased in LPS $+L_{X A_{4}}+R p-c A M P$ group when compared with LPS $+\mathrm{LXA}_{4}$ group (Figure 9).

\section{DISCUSSION}

ALI/ARDS is a common, devastating clinical syndrome that affects large numbers of patients and has up to $40 \%$ mortality [10]. The current treatment for ALI/ARDS is aimed at removal of polymorphonuclear neutrophils, and alveolar fluid re-absorption. Cation and anion channels and ion transporters are involved in the clearance of alveolar fluid. Several studies have reported the key role of ENAC not only in the uptake of $\mathrm{Na}+$ from the alveolar fluid but also in the clearance of the fluid itself $[2,3,11-13]$. In the present study, it has been clearly demonstrated that $L X A_{4}$ upregulated the expressions of the mRNAs and proteins of the $\alpha, \beta$ and $\gamma$ subunits of ENAC in normal and LPS-treated human alveolar epithelial cells. These up-regulations were both dose- and time-dependent. These effects were blocked by the inhibitor of AhR and Rp-cAMP, an 
A
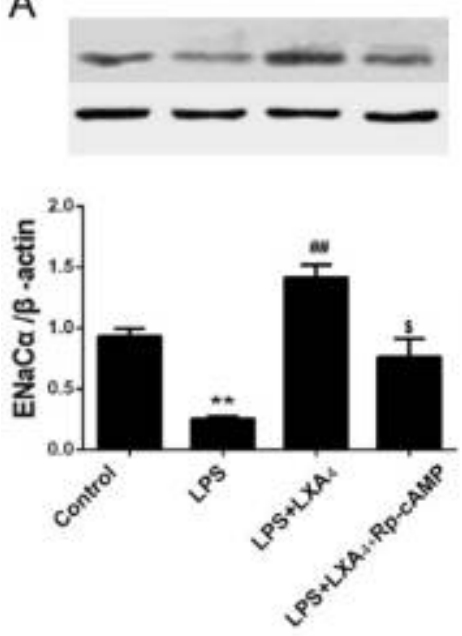

B
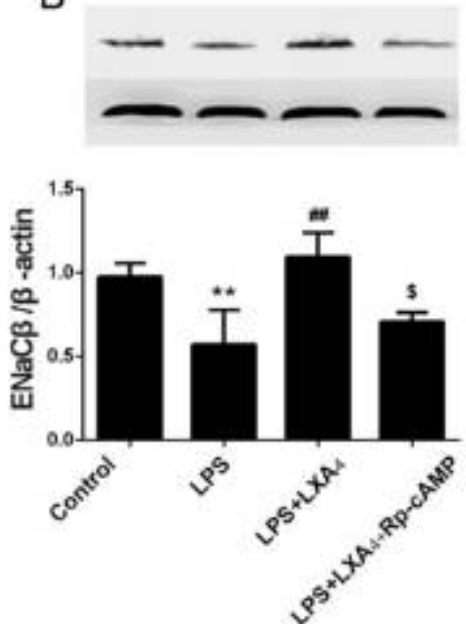
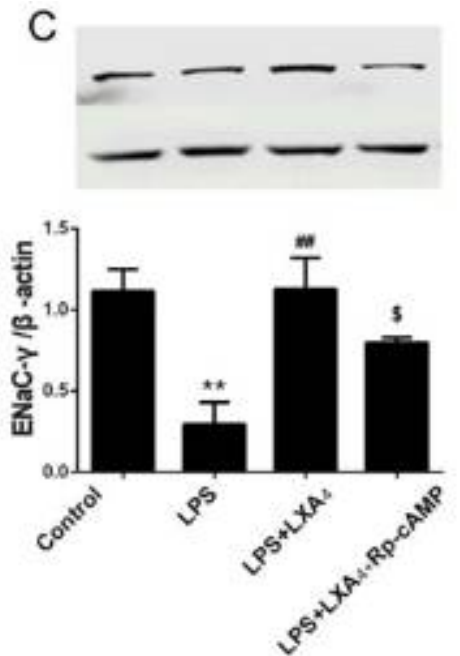

Figure 9: $\mathrm{LXA}_{4}$ increased ENaC expression dependent on cAMP in A549 cells stimulated with LPS. Cells were treated with RP-cAMP (cAMP inhibitor, $10 \mathrm{uM})$ in the presence of $L X A_{4}\left(10^{-7} \mathrm{M}\right)$ and LPS $(1 \mathrm{ug} / \mathrm{mL})$ for $24 \mathrm{~h}$. After incubation, the cells were harvested, and sonicated. ENaC $\alpha, \beta$ and $y$ subunits protein expression in the cell lysates were determined by western blotting using a specific antibody

indication that $L X A_{4}$ enhanced the expression of $\mathrm{ENaC}$ through AhR-cAMP signaling pathway.

The expressions of the mRNAs and proteins of the $\alpha, \beta$ and $y$ subunits of ENAC were decreased by $1 \mu \mathrm{g} / \mathrm{mL}$ LPS, but these decreases were dosedependently reversed by $L A_{4}$, with maximal effect at $10^{-7} \mathrm{M}$. These findings are in disagreement with recent reports which suggest that $\mathrm{LXA}_{4}$ enhanced the expression of ENaC in A549 alveolar cells [10]. Interestingly, it was found that $10^{-6} \mathrm{M} L X A_{4}$ was less effective than $10^{-7} \mathrm{M}$. This implies that the effect of $L X A_{4}$ was not concentration-dependent. It is also likely that at $10^{-6} \mathrm{M}, \mathrm{LXA}_{4}$ actually brought about decreased expression of ENaC. Thus, $10^{-6} \mathrm{M} \mathrm{LXA}_{4}$ was used in subsequent experiments. $\mathrm{LXA}_{4}$ significantly improved the expressions of the $\alpha, \beta$ and $y$ subunits of ENAC in healthy A549 cells and in LPS-treated cells at 6, 12 and $24 \mathrm{~h}$. The expressions in the LPS group at $24 \mathrm{~h}$ were much lower than those at $6 \mathrm{~h}$ and $12 \mathrm{~h}$, suggesting a greater degree of cellular damage at $24 \mathrm{~h}$ than at any of the other periods. It has been reported that $\mathrm{LXA}_{4}$ increased $\mathrm{ENaC}$ concentrations in primary rat alveolar type II epithelial cells exposed to LPS $24 \mathrm{~h}$ [21]. Therefore, in subsequent studies, the effect of $\mathrm{LXA}_{4}$ on ENaC expression in LPS-treated A549 cells was evaluated at $24 \mathrm{~h}$. The results obtained in the present study show that $\mathrm{LXA}_{4}$ regulates the expression of $\mathrm{ENaC}$ in healthy and pathological states. This is consistent with previous results which suggest that $L A_{4}$ may be involved in endotoxin-induced ALI/ARDS [14].

The expression of the mRNA of the a subunit of ENAC was decreased following exposure to 1 $\mu \mathrm{g} / \mathrm{mL}$ LPS for $6 \mathrm{~h}$, but there were no significant changes in the expressions of mRNAs for the $\beta$ and $y$ subunits. This shows that the expression of mRNA of the sodium channel was inhibited by LPS. In a previous study, it was reported that mouse alveolar epithelial cells treated with LPS for $8 \mathrm{~h}$ had significantly reduced expressions of mRNAs for the $\alpha, \beta$ and $\gamma$ subunits of ENAC [27]. The fact that $L X A_{4}$ increased mRNA expressions for $\alpha, \beta$ and $y$ of ENAC at $6 \mathrm{~h}$ indicates that $\mathrm{LXA}_{4}$ protected the cells by enhancing ENaC gene translation.

LXs mediate their effects by interacting with one or more specific receptors such as ALX, CysLTR1, CysLTR2 and AhR. In this study, CysLTR2 and AhR were the only receptors present on the basolateral membrane of the A549 cells, which is consistent with previous findings showing that A549 cells expressed mRNAs of cysLT $T_{2}$ and AhR only [16-18]. The beneficial effects of $\mathrm{LXA}_{4}$ were reversed by ANF, an $A h R$ antagonist, but not by the $\mathrm{cysLT}_{2}$ receptor antagonist BAY-u9773. This is clear evidence that the effect of $L X A_{4}$ on expression of the $\alpha, \beta$ and $\gamma$ subunits of ENAC occurred through binding to AhR.

CAMP and CGMP are important second messengers by which cells transduce extracellular signals into intracellular responses. Extracellular signals interact with GPCRs to activate adenylate cyclase (AC) and increase intracellular CAMP levels. A previous study showed that LPS-induced immune responses are associated with decreases in intracellular cAMP levels [7]. It has been reported that LPS activates inhibitory $G$ protein, thereby inhibiting formation of CAMP [19]. Stimulation by CAMP enhances $\mathrm{Na}^{+}$transport and the activity of Na-K-ATPase in 
the plasma membrane $[20,21]$. This is in agreement with a model that suggests that at the early stages, cAMP enhances the transport of $\mathrm{ENaC}$ to the cell surface, whereas the synthesis of $\mathrm{ENaC}$ is necessary for the sustenance of this effect [20]. Extracellular signals also interact with GPCR to activate guanylyl cyclases (GC) and increase intracellular cGMP levels. Studies have shown that $A h R$ induces signaling pathways that entail ERK, PKA, MMP9 and CAMP, cGMP and $\mathrm{Ca}^{2+}[22]$. It has also been shown that $\mathrm{AhR}$ is more sensitive to the cAMP signaling pathway $[22,23]$, and that cAMP induces nuclear translocation of the AhR [24]. Thus it appears that the two signaling pathways for regulation of ENaC, cAMP, and cGMP are compartmentalized. Levels of intracellular cAMP were decreased after LPS stimulation, and the decreases were reversed by $L X A_{4}$ in the LPS group. The reversal of the effects of $L X A_{4}$ by ANF and Rp-cAMP, without any significant effects on intracellular cGMP levels indicates that $\mathrm{LXA}_{4}$ increases the levels of cAMP through AhR. Thus $L X A_{4}$ up-regulates the expressions of $\alpha, \beta$ and $\mathrm{Y}$ subunits of ENaC by activating CAMP via AhR. The role of $L_{X A_{4}}$ in LPS-treated human alveolar epithelial cells can be depicted as indicated in Figure 10.

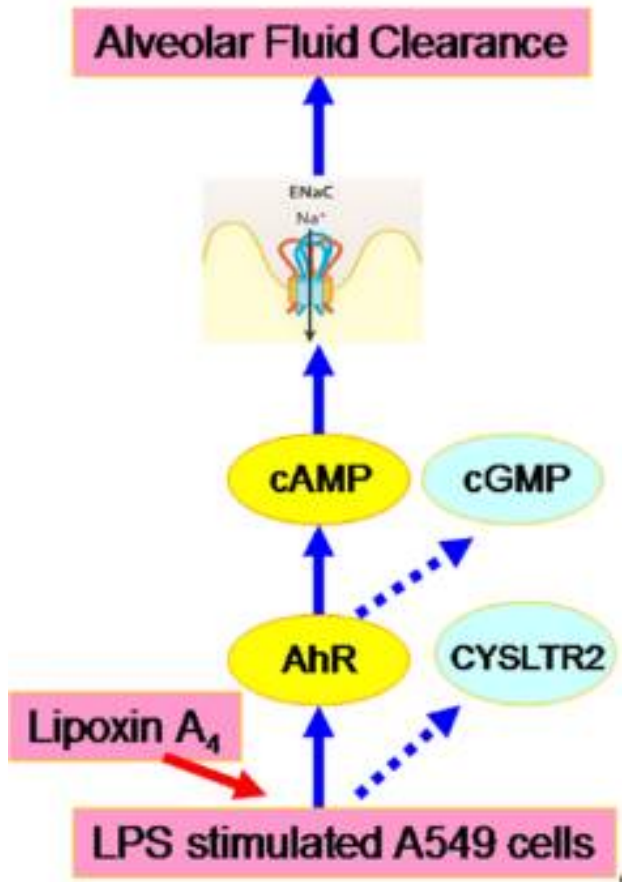

Figure 10: Modulation of sodium channel in human alveolar epithelial cells $\mathrm{LXA}_{4}$ through AhR-cAMP-dependent pathway

\section{CONCLUSION}

This study has provided evidence for upregulation of ENAC in normal and LP-stimulated
A549 alveolar epithelial cells, most probably through the AhR-cAMP signaling pathways. Thus, it is proposed that $L X A_{4}$ can be applied for the induction of ENaC expression in the treatment of ALI/ARDS and related diseases.

\section{DECLARATIONS}

\section{Acknowledgement}

This work was sponsored by grants from Natural Science Foundation of Zhejiang Province of China (LY14H150011) and The Scientific and Technology Project of Wenzhou City of Zhejiang Province (Y20150038).

\section{Conflict of Interest}

No conflict of interest associated with this work.

\section{Contribution of Authors}

The authors declare that this work was done by the authors named in this article and all liabilities pertaining to claims relating to the content of this article will be borne by them.

\section{Open Access}

This is an Open Access article that uses a funding model which does not charge readers or their institutions for access and distributed under the terms of the Creative Commons Attribution License (http://creativecommons.org/licenses/by/ 4.0) and the Budapest Open Access Initiative (http://www.budapestopenaccessinitiative.org/rea d), which permit unrestricted use, distribution, and reproduction in any medium, provided the original work is properly credited.

\section{REFERENCES}

1. Pittet JF, Griffiths MJD, Geiser T, Kaminski N, Dalton SL, Huang $X$, Lou ASB, Gotwals PJ, Koteliansky VE, Matthay MA. TGF- $\beta$ is a critical mediator of acute lung injury. J Clin Investig 2001; 107(12): 1537-1544.

2. Berthiaume $Y$, Matthay MA. Alveolar Edema Fluid Clearance and Acute Lung Injury. Respir Physiol Neurobiol 2007; 159(3): 350.

3. Matthay MA, Folkesson HG, Clerici C. Lung epithelial fluid transport and the resolution of pulmonary edema. Physiol Rev 2002; 82(3): 569-600.

4. Parthasarathy PT, Galam L, Bao H, Yunus A, Abuelenen T, Castillo A, Ramanathan GK, Cox Ruan J, Kolliputi N. MicroRNA 16 Modulates Epithelial Sodium Channel in Human Alveolar Epithelial Cells. Biochem Biophys Res Commun 2012; 426(2): 203-208. 
5. Bandeira-Melo C, Bozza PT, Diaz BL, Cordeiro RS, Jose $P J$, Martins MA, Serhan CN. Cutting edge: lipoxin $(L X)$ A4 and aspirin-triggered 15-epi-LXA4 block allergeninduced eosinophil trafficking. J Immunol 2000; 164(5): 2267.

6. Serhan CN. Resolution phase of inflammation: novel endogenous anti-inflammatory and proresolving lipid mediators and pathways. Annu Rev Immunol 2007; 25(1): 101-137.

7. Kieran NE, Maderna P, Godson C. Lipoxins: potential anti-inflammatory, proresolution, and antifibrotic mediators in renal disease. Kidney Int 2004; 65(4): 1145-1154.

8. Al-Alawi M, Buchanan P, Verriere V, Higgins G, Mccabe $O$, Costello RW, Mcnally $P$, Urbach $V$, Harvey $B J$. Physiological levels of lipoxin A4 inhibit ENaC and restore airway surface liquid height in cystic fibrosis bronchial epithelium. Physiol Rep 2014; 2(8).

9. Wang $Q$, Lian $Q Q$, Li R, Ying $B Y$, He $Q$, Chen F, Zheng $X$, Yang $Y$, Wu DR, Zheng SX. Lipoxin A(4) activates alveolar epithelial sodium channel, Na,K-ATPase, and increases alveolar fluid clearance. Am J Respir Cell Mol Biol 2013; 48(5): 610-618.

10. Qi W, Li H, Cai XH, Gu JQ, Meng J, Xie HQ, Zhang JL, Chen J, Jin XG, Tang Q. Lipoxin A4 activates alveolar epithelial sodium channel gamma via the microRNA21/PTEN/AKT pathway in lipopolysaccharide-induced inflammatory lung injury. Lab Invest 2015; 95(11): 1258.

11. Jin SW, Zhang L, Lian QQ, Liu D, Wu P, Yao SL, Ye DY. Posttreatment with aspirin-triggered lipoxin A4 analog attenuates lipopolysaccharide-induced acute lung injury in mice: the role of heme oxygenase-1. Anaesth Analg 2007; 104(2): 369-377.

12. Livak KJ, Schmittgen TD. Analysis of relative gene expression data using real-time quantitative $P C R$ and the 2(-Delta Delta C(T)) Method. Methods 2001; 25(4): 402-408.

13. Matthay MA, Ware LB, Zimmerman GA. The acute respiratory distress syndrome. Ann Intern Med 2004; 141(6): 460-470.

14. Eaton DC, Helms MN, Koval M, Bao HF, Jain L. The Contribution of Epithelial Sodium Channels to Alveolar Function in Health and Disease. Annu Rev Physiol 2009; 71(71): 403-423.
15. Lazrak A, Samanta A, Matalon S. Biophysical properties and molecular characterization of amiloride-sensitive sodium channels in A549 cells. Am J Physiol Lung Cell Mol Physiol 2000; 278(4): 848-857.

16. Sartori $C$, Matthay MA. Alveolar epithelial fluid transport in acute lung injury: new insights. Eur Respir J 2002; 20(5): 1299-1313.

17. Levy BD, Sanctis GTD, Devchand PR, Kim E, Ackerman $K$, Schmidt B, Szczeklik W, Drazen JM, Serhan CN, Lipoxins and Aspirin-Triggered Lipoxins in Airway Responses. 2003: Springer US. 19-23.

18. Dickie AJ, Rafii B, Piovesan J, Davreux C, Ding J, Tanswell AK, Rotstein O, O'Brodovich $\mathrm{H}$. Preventing endotoxin-stimulated alveolar macrophages from decreasing epithelium $\mathrm{Na}+$ channel (ENaC) mRNA levels and activity. Pediatr Res 2000; 48(3): 304-310.

19. Romano M, Recchia I, Recchiuti A. Lipoxin receptors. Scientific World Journal 2007; 7(1): 1393.

20. Brink C, Dahlén SE, Drazen J, Evans JF, Hay DWP, Nicosia S, Serhan CN, Shimizu T, Yokomizo $T$. International Union of Pharmacology XXXVII. Nomenclature for Leukotriene and Lipoxin Receptors. Pharmacol Rev 2003; 55(1): 195.

21. Lavrova EA, Nikolaeva SD, Fok EM, Bakhteeva VT, Parnova RG. Lipopolysaccharide E. coli inhibits the arginine-vasotocin-induced increase of osmotic water permeability in the frog urinary bladder. Rossiskii Fiziologicheski Zhurnal Imeni I.m.sechenova 2009; 95(3): 215-224.

22. Gerrits AJ, Koekman $C A$, Yildirim $C$, Nieuwland $R$, Akkerman JWN. Insulin inhibits tissue factor expression in monocytes. Thrombosis and Haemostasis 2009; 7(1): 198-205.

23. Thomas CP, Campbell JR, Wright PJ, Husted RF. cAMPstimulated $\mathrm{Na}+$ transport in $\mathrm{H} 441$ distal lung epithelial cells: role of PKA, phosphatidylinositol 3-kinase, and sgk1. Am J Physiol Lung Cell Mol Physiol 2004; 287(4): L843-L851.

24. Lecuona E, Minin A, Trejo HE, Chen J, Comellas AP, Sun $H$, Grillo $D$, Nekrasova OE, Welch LC, Szleifer I. Myosin-Va restrains the trafficking of $\mathrm{Na+} / \mathrm{K}+-$ ATPasecontaining vesicles in alveolar epithelial cells. J Cell Sci 2009; 122(21): 3915-3922. 